\title{
Parathyroid Hormone
}

National Cancer Institute

\section{Source}

National Cancer Institute. Parathyroid Hormone. NCI Thesaurus. Code C41027.

Parathyroid hormone (115 aa, $13 \mathrm{kDa}$ ) is encoded by the human PTH gene. This protein is involved in the modulation of calcium ion and phosphate concentration in the blood. 